Public Health of Indonesia

Rosanty A. Public Health of Indonesia. 2016 September;2(3): 149-154

http://stikbar.org/ycabpublisher/index.php/PHI/index

Original Research

\title{
CORRELATION BETWEEN PERSONAL HYGIENE AND INFECTION OF INTESTINAL HELMINTHS AMONG STUDENTS AT THE PUBLIC ELEMENTARY SCHOOL 3 ABELI, KENDARI INDONESIA
}

\author{
Anita Rosanty* \\ Department of Nursing, Polytechnic of Health Kendari, Ministry of Health of te Republic of Indonesia
}

Accepted: 1 September 2016

*Correspondence:

Anita Rosanty, SST., M.Kes

Department of Nursing, Polytechnic of Health Kendari, Ministry of Health of the Republic of Indonesia

E-mail : unesa200852@yahoo.com

Copyright: (C) the author(s), YCAB publisher and Public Health of Indonesia. This is an open-access article distributed under the terms of the Creative Commons Attribution Non-Commercial License, which permits unrestricted non-commercial use, distribution, and reproduction in any medium, provided the original work is properly cited.

\begin{abstract}
Backgrounds: Intestinal helminth is one of diseases derived from environment and still becomes a helath problem in Indonesia until today. The high number of intestinal helminth prevalence in Indonesia is related with bad personal hygiene, including handwashing habit, nail hygiene, and foot-wear wearing habit.

Objectives: The objective of this research is to know the correlation between the infection of intestinal helminths with handwashing habit, nail hygiene, and foot-wear wearing habit of the students at the Public Elementary School 3 Abeli Kendari Indonesia.

Methods: This research was a cross sectional study with an observational analysis. There was 134 respondents were recruited using total sampling.

Results: Findings revealed that there were 27 respondents $(20.1 \%)$ who had handwashing habit with good category, and 107 respondents (79.9) had handwashing habit with poor category. There were 32 respondents $(23.9 \%)$ had nail hygiene with poor category, and 102 respondents $(76.1 \%)$ had nail hygiene with good category. There were 52 respondents $(38.8 \%)$ had not good foot-wear wearing habit, and 82 respondents $(61.2 \%)$ had good foot-wear wearing habit. There was a correlation between handwashing habit, nail hygiene, foot-wear wearing habit and the infection of intestinal helminth among students of public elementary school 3 Abeli Kendari city

Conclusion: There were significant relationship between personal hygiene and intestinal helminth. Thus, it is suggested that parents, school teachers, and other significant persons need to maintain the habit of personal hygiene of the students that consists of handwashing habit, nail hygiene, foot-wear wearing habit.
\end{abstract}

Key words: personal hygiene, intestinal helminths, infection.

\section{INTRODUCTION}

Many wormy infections were found on society who live in developing countries, especially in rural areas. It is estimated that more than two billion people were infected in the worldwide of which about 300 million suffer of severe worm infection and an estimated 150,000 deaths occur each year due to wormy infections. ${ }^{1}$ Intestinal helminth disease was one of diseases which prevalent occur in society but have got less attention. ${ }^{2}$ In Indonesia, 
the number of morbidity because of intestine helminthes or stomach infected was quite high. ${ }^{3}$ It was because of the geographical location of Indonesia in the tropics area having a hot climate but humid. In an enabling environment, ${ }^{4}$ intestinal helminths can breed well, especially by worms that were transmitted through the ground. The transmission of intestinal helminthes may spread through contaminated food, ${ }^{5}$ water, ${ }^{1}$ through contaminated air or directly through contaminated hands of worm eggs which are infective.

Nowadays, the infection of
helminthes was one disease-based environment that is still a problem for public health in Indonesia. The high of prevalence number of worms in Indonesia was closely related to several factors, including: 1) Indonesia is located in the tropical climate which is an ideal place for the development of worm eggs, 2) Unhealthy living habits, such as bowel habits in any places and without footwear, and 3) poor residents having a high risk susceptible to infect the worms, such as intestinal helminthes which transmitted through soil or called as soil transmitted helminthes. The main species worms are roundworm (Ascaris lumbricoides), hookworm (Ancylostoma duodenale and Necator americanus) and whipworm (Trichuris trichura) ${ }^{6}$

Survey found that the group of elementary school students had a high prevalence of helminthes, approximately $60-80 \%$. The high number of helminthes on this group of students because they often play or contact with the ground in where intestinal helminthes was growed and developed. Although, the number of helminthes was still relatively high, but the prevention and eradication of the infection was not performed optimally. It was because of intestineal helminth infection usually got insufficient attention, especially from the parents. Furthermor, the impact of the helminthes infection could not be directly seen.

Generally, the factors that influence the intestinal helminth infection such as climatic conditions that are suitable for its growth, the condition of environmental sanitation and bad personal hygiene, as well as the socio-economic condition and low education. Personal hygiene is an attempt to prevent diseases caused by environmental influences in order to achieve optimal health status. Personal hygiene is closely related to intestinal helminth infections, such as hand washing, nails cleaning, and foot-wear wearing. The transmission of eggs or worm larva could occur through the nail that is containing eggs/larva worm, and then enter to the mouth from the food if the child does not wash their hands before eating or does not keep the clean of the nails. ${ }^{1}$

Pilot study indicated that the students of the public elementary school 3 Abeli Kendari city had bad personal hygienes and foot-wear wearing habit. However, little is known about the number of helminth infection of students in the public elementary school 3 Abeli Kendari city. Thus, the objective of this study is to determine the relationship of hand washing habit, nails hygiene, and wearing foot-wear wearing habit with intestinal helminth infections among students of the public elementary school 3 Abeli Kendari, Indonesia.

\section{METHODS}

This was a cross sectional study with an observational analysis. There was 134 respondents were recruited using total sampling technique. It was conducted at the Public Elementary School 3 Abeli Kendari from August to November 2015. Questionnaire was used to identify personal hygiene, consisting of: 12 questions with vary question items, 
namely: 6 items of hand washing habits, 3 items of nail hygiene, and 3 items of footwear wearing habit with score 2 (highest), 1 (medium), and 0 (lowest). Data of Intestinal helminth infection on students of
State Elementary School 3 Abeli Kendari city were examined in the parasitological laboratory of Health Analyst Department, Poltekkes, and Health Ministry, Kendari.

\section{RESULTS}

\section{Distribution of prevalence of intestinal helminth infections}

Of 134 respondents, there were 55 respondents $(41.0 \%)$ were positively infected by intestine helminths, and 79 respondents $(59.0 \%)$ were not infected by intestine helminths

Table 1: Distribution of prevalence of intestinal helminth infections among students

\begin{tabular}{|c|l|l|l|}
\hline No. & $\begin{array}{c}\text { Intestinal Helminths } \\
\text { infection }\end{array}$ & F & \% \\
\hline 1 & Positive & 55 & 41.0 \\
\hline 2 & Negative & 79 & 59.0 \\
\hline \multicolumn{2}{|c|}{ Total } & 134 & 100 \\
\hline
\end{tabular}

Table 2: Distribution of respondents based on hand washing habits

\begin{tabular}{|c|c|c|c|}
\hline No. & $\begin{array}{c}\text { Hand washing } \\
\text { habits }\end{array}$ & $\mathbf{F}$ & $\%$ \\
\hline 1 & Good & 27 & 20.1 \\
\hline 2 & Not Good & 107 & 79.9 \\
\hline & Total & 134 & 100 \\
\hline
\end{tabular}

Table 2 showed that 107 respondents $(79.9 \%)$ had a good washing hand habit, and 27 respondents (20.1\%) had not good hand washing habits.
Table 3: Distribution of respondents based on the nails hygiene.

\begin{tabular}{|c|l|l|l|}
\hline No. & Nail hygiene & F & \% \\
\hline 1 & Not Good & 32 & 23.9 \\
\hline 2 & Good & 102 & 76.1 \\
\hline \multicolumn{2}{|c|}{ Total } & 134 & 100 \\
\hline
\end{tabular}

Table 3 showed that 32 respondents $(23.9 \%)$ had not good nail hygiene, and 102 respondents $(76.1 \%)$ had a good nail hygiene.

Table 4: Distribution of respondents based on the habit of wearing footwear

\begin{tabular}{|c|l|l|l|}
\hline No. & $\begin{array}{l}\text { Foot-wear } \\
\text { wearing Habits }\end{array}$ & F & \% \\
\hline 1 & Not always & 52 & 38.8 \\
\hline 2 & Always & 82 & 61.2 \\
\hline \multicolumn{2}{|c|}{ Total } & 134 & 100 \\
\hline
\end{tabular}

Table 4 showed that 52 respondents (38.8\%) who had a habit that was not wearing footwear, and there were 82 respondents $(61.2 \%)$ had good habits in wearing footwear.

\section{Relationship of handwashing habit, nail hygiene, foot-wear wearing habit and intestinal helminth infections among students of the Public Elementary School 3 Abeli}

Table 5: Relationship of handwashing habit and intestinal helminth infections among students of the Public Elementary School 3 Abeli

\begin{tabular}{|c|c|c|c|c|c|c|}
\hline & \multicolumn{4}{|c|}{ Helminthes } & \multirow{3}{*}{ p-value } \\
\hline & & \multicolumn{2}{|c|}{ Negative } & \multicolumn{2}{|c|}{ Positive } & \\
\hline & & n & $\%$ & n & $\%$ & \\
\hline \multirow{2}{*}{$\begin{array}{c}\text { Habit of } \\
\text { washing hands }\end{array}$} & Not Good & 56 & 56.3 & 51 & 47.7 & \multirow{2}{*}{0.002} \\
\hline & Good & 23 & 85.2 & 4 & 14.8 & \\
\hline \multicolumn{2}{|c|}{ Total } & 79 & 59.0 & 55 & 41.0 & \\
\hline
\end{tabular}


Table 5 indicated that 55 respondents (41\%) were positively infected by intestinal helminth, consisting of: 51 respondents $(47.7 \%)$ had not good handwashing habit and 4 respondent $(14.8 \%)$ had good hand washing habit. Chi square test showed p-value 0.002 , less than 0.05 , which means that there was a relationship between handwashing habits and intestinal helminthes infections among students of Public Elementary School 3 Abeli Kendari city.

Table 6: Nail hygiene with intestine helminthes infections on students of State Elementary School 3 Abeli Kendari city.

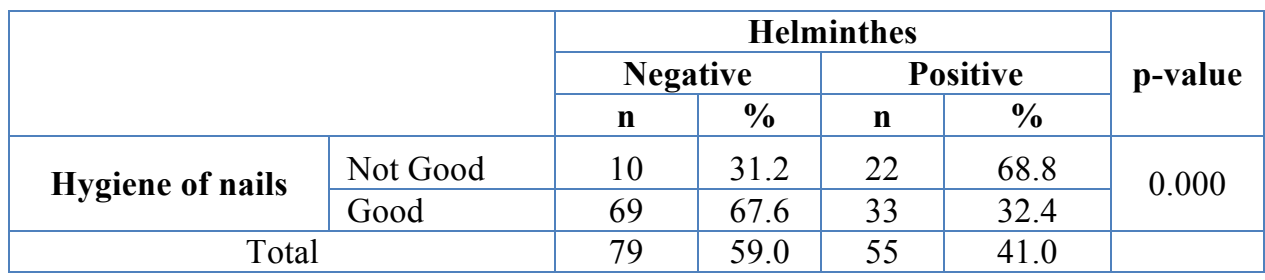

Table 6 showed that 79 respondents (59\%) were not infected by intestine helminthes that consist of: 10 respondents $(31.2 \%)$ who had bad nail hygiene and 69 respondents $(67.6 \%)$ who had good nail hygiene. On the other hand, the 55 respondents $(41 \%)$ were infected by intestine helminthes infection there were 22 respondents who had not good nails hygiene and 33 respondents $(32.4 \%)$ were good nail hygiene. Chi square test indicated $\mathrm{p}$-value $=0.000$ less than the value $\alpha$ of 0.05 , which means there was a relationship between nails hygiene and intestinal helminth infections among students of Public Elementary School 3 Abeli Kendari city.

Table 7: The habit of wearing footwear with intestine helminthes infections on students of State Elementary School 3 Abeli Kendari city.

\begin{tabular}{|c|c|c|c|c|c|c|}
\hline & & \multicolumn{4}{|c|}{ Helminthes } & \multirow{3}{*}{ p-value } \\
\hline & & \multicolumn{2}{|c|}{ Negative } & \multicolumn{2}{|c|}{ Positive } & \\
\hline & & $\mathbf{n}$ & $\%$ & n & $\%$ & \\
\hline \multirow{2}{*}{$\begin{array}{l}\text { Foot-wear } \\
\text { wearing habit }\end{array}$} & Not Good & 14 & 30.7 & 38 & 21.3 & \multirow{2}{*}{0.000} \\
\hline & Good & 65 & 48.3 & 17 & 33.7 & \\
\hline \multicolumn{2}{|c|}{ Total } & 79 & 59.0 & 55 & 41.0 & \\
\hline
\end{tabular}

Table 7 showed that 79 respondents $(59 \%)$ were not infected by intestinal helminth consisting of: 14 respondents $(30.7 \%)$ who had bad foot-wear wearing habit and 65 respondents had good footwear wearing habit. In contrast, 55 respondents $(41 \%)$ were positively infected by the intestinal helminths that consist of 38 respondents who had not good foot- wear wearing habit and 17 respondents (33.7\%) who had a good foot-wear wearing habit. Chi square test showed $\mathrm{p}$ value $=0.000$ less than the value $\alpha$ of 0.05 , which means there was a relationship between the habit of wearing footwear and intestinal helminth infections among students of Public Elementary School 3 Abeli Kendari city. 


\section{DISCUSSION}

\section{Hand Washing Habits}

The results indicated that students of Public Elementary School 3 Abeli Kendari city averagely had not good handwashing habit after playing. It might be because of the lack of knowledge related the socialization and implementation efforts of hand washing habits in the schools. However, lack of awareness and facilities to provide clean water could be the causes of the habit. In this study, there were 17 respondents who had good handwashing habits but positively infected by the intestinal helminth. It happened because the worm transmission was not only through the hands that enter with the food, ${ }^{1}$ but also through pores that enter through the foot. One way of the worm eggs enter ${ }^{7}$ into the body was through oral cavity with the food. It might occur if hands are not washed carefully, especially after playing in the ground, ${ }^{8}$ for instance, if students can just easily eat snack without washing hand, then worm eggs that stick in hand come in with the food into oral cavity. ${ }^{9}$

\section{Hygiene of Nails}

According to the research result, of 33 respondents (32.4\%) who had good nail hygiene were positively infected by intestinal helminths. It occurrs because the worms can enter the body through the foot. However, good nail hygiene with short nails and clean prevents intestineal helminthes infection because the egg or larval worms did not stay on the sidelines of the nail. ${ }^{3}$ Long nails could be a place for eggs or wormy larva to settle feces, which are also ingested with food when children did not wash their hands before eating. ${ }^{10}$

In contrast, of 10 respondents (31.2\%) who had not good habit of cutting nails but having negative intestinal helminths. It is possibly because respondents had a good habit for washing hands although having a bad habit of cutting their nails. So, the eggs, ${ }^{7}$ larva ${ }^{4}$ of the worm on the sidelines of the nail will die with handwashing with soap. ${ }^{2}$

\section{Wearing Footwear Habit}

Of 17 respondents (33.7\%) who had good foot-wear wearing habit 38 respondents who had not good foot-wear wearing habit were having positive intestinal helminths. It is consistent with previous study that worms can enter the body through the soles of the feet. ${ }^{11}$ Larva of the worm enter into the blood vessel until the intestine become a breeding wormy continually. ${ }^{12}$ However, although respondents have a good habit in wearing foot wear, but not having a good habit of handwashing and nail hygiene, intestinal helminths might just occur.

\section{CONCLUSIONS}

It can be concluded that there were relationships between handwashing habit, nail hygiene, foot-wear wearing habit and intestinal helminth infections among students of Public Elementary School 3 Abeli Kendari city, Indonesia. It is suggested that parents, school teachers, and other significant persons need to maintain the habit of personal hygiene of the students that consists of handwashing habit, nail hygiene, foot-wear wearing habit.

\section{REFERENCES}

1. Ibidapo CA, Okwa O. The prevalence and intensity of soil transmitted helminths in a rural community, Lagos Suburb, South west Nigeria. International Journal of Agriculture and Biology. 2008;10(1):89-92.

2. Ekpenyong EA, Eyo JE. Prevalence of intestinal helminths infections among schooling children in tropical semi urban communities. Animal 
Research

International. 2008;5(1):804-810.

3. Umar Z. Perilaku cuci tangan sebelum makan dan kecacingan pada murid SD di Kabupaten Pesisir Selatan Sumatera Barat. Kesmas: Jurnal Kesehatan Masyarakat Nasional. 2008;2(6):249-254.

4. Oyemade A, Omokhodion FO, Olawuyi JF, Sridhar MK, Olaseha IO. Environmental and personal hygiene practices: risk factors for diarrhoea among children of Nigerian market women. Journal of Diarrhoeal Diseases Research. 1998:241-247.

5. Idowu O, Rowland S. Oral fecal parasites and personal hygiene of food handlers in Abeokuta, Nigeria. African health sciences. 2006;6(3):160-164.

6. Knopp S, Steinmann P, Keiser J, Utzinger J. Nematode infections: soil-transmitted helminths and Trichinella. Infectious disease clinics of North America. 2012;26(2):341358.

7. Goldman N, Pebley AR, Beckett M. Diffusion of ideas about personal hygiene and contamination in poor countries: evidence from Guatemala. Social science \& medicine. 2001;52(1):53-69.

8. Saharman S, Mayulu N, Hamel R. Hubungan Personal Hygiene Dengan
Kecacingan Pada Murid Sekolah Dasar Di Kabupaten Bolaang Mongondow Utara. Jurnal Keperawatan. 2013;1(1).

9. Rathnayaka RKT, Wang Z-j. Prevalence and effect of personal hygiene ontransmission of helminthes infection among primary school children living in slums. PREVALENCE. 2012;2(7).

10. Askarian M, Khalooee A, Emroodi N. Personal hygiene and safety of governmental hospital staff in Shiraz, Islamic Republic of Iran. 2006.

11. Winita R, Mulyati AH. Upaya pemberantasan kecacingan di sekolah dasar. Jurnal Makara. 2012;16(2):65-71.

12. Nel S, Lues J, Buys E, Venter P. The personal and general hygiene practices in the deboning room of a high throughput red meat abattoir. Food control. 2004;15(7):571-578.

Cite this article as: Rosanti A. Correlation between Personal Hygiene and Infection of Intestinal Helminths among Students at the Public Elementary School 3 Abeli, Kendari Indonesia. Public Health of Indonesia 2016; 2(3):149-154 